\title{
O Bairro Rural como Identidade Territorial: a especificidade da abordagem do campesinato na geografia.
}

\section{Larissa Mies Bombardi ${ }^{1}$}

\section{RESUMO}

Este artigo visa discutir e apontar a importância do conceito de bairro rural na geografia e, em especial na geografia agrária. Diferentemente do entendimento corrente sobre Bairro Rural, em que este é interpretado de maneira isolada, pois o entendimento tradicional de campesinato é também aquele que envolve uma certa parcela de isolamento, proponho a compreensão do Bairro Rural como uma unidade territorial criada a partir da identidade territorial, e, o que é fundamental, se reproduzindo no interior do capitalismo. Esta unidade territorial forjada pelo trabalho camponês ganha uma configuração que difere diamentralmente daquela em que as relações tipicamente capitalistas é que dão à configuração ao território, ou seja, onde temos a territorialização do capital. A unidade territorial (bairro rural) é, desta forma, fruto da identidade territorial criada a partir da sociabilidade camponesa. É a teia de relações estabelecida entre as famílias componesas que dá ao grupo sua identidade, esta por sua vez, se materializa no território, dando a este a dimensão peculiar do Bairro Rural. Esta interpretação do bairro rural nos permite, portanto, abarcar, compreender e lançar luz sobre o lugar do campesinato e de sua reprodução nesta sociedade.

\section{PALAVRAS-CHAVE:}

bairro rural, campesinato, identidade, território.

\footnotetext{
${ }^{1}$ Geógrafa, Mestre e Doutoranda em Geografia Humana (Programa de Pós Graduação em Geografia Humana- Depto de Geografia - FFLCH/USP).
} 
ABSTRACT

This paper aims to discuss and to point the importance of the concept of "bairro rural” to Geography, especially to Agrarian Geography. Different from the common understanding of "bairro rural", in which it is interpreted in an isolated manner, because the traditional understanding of peasants is also the one that involves a certain parcel of isolation, I propose the understanding of "bairro rural" as a territorial unit created from the territorial identity, and, what is fundamental here, reproducing itself inside capitalism. This territorial unit produced by peasant work gains a configuration which is totally different from the one in which the typically capitalist relations give territory a configuration, that is, where we have the capital territorialization. The territorial unit ("bairro rural") is, in this manner, the result of territorial identity created from the peasants sociability. It is this relations' web among the peasant families that gives the group its identity, and it materializes in the territory, giving it the peculiar dimension of "bairro rural". So, this interpretation of "bairro rural" permits us including, understanding and enlightening the peasants place and their reproduction in this society.

KEYWORDS: “bairro rural”, peasants, identity, territory.

O conceito de Bairro Rural na Geografia, especialmente na Geografia Agrária, merece uma abordagem singular posto que nos fornece elementos importantíssimos para a interpretação e a análise da realidade do campo.

Para discutir o conceito de Bairro Rural vou lançar mão do estudo realizado a respeito do Bairro Reforma Agrária ${ }^{2}$ (Campinas-SP).

Diferentemente do entendimento corrente sobre Bairro Rural, especialmente aqueles cunhados por Müller (1946) e Queiroz (1967), em que o Bairro Rural é interpretado de maneira isolada, pois o entendimento que têm de sitiante é também aquele que envolve uma certa parcela de isolamento, proponho a compreensão do Bairro Rural como uma unidade territorial criada a partir da identidade territorial. Esta interpretação permite abarcar, compreender e lançar luz sobre o lugar do campesinato nesta sociedade.

Trabalho, portanto, com o conceito de território como o conceito geográfico central de abordagem da realidade. Ele está aqui sendo entendido, conforme

\footnotetext{
${ }^{2}$ Ver Bombardi, 2004.
} 
Raffestin (1993:160), como resultado da inter-relação estabelecida pelos três eixos de seu tripé: espaço, tempo e relações sociais.

O território é, desta forma, fruto das relações sociais que se estabelecem no espaço ao longo do tempo.

Segundo Oliveira (1988b, p.109): “as transformações temporais encontram sua consolidação nas transformações espaciais”, ou seja, o espaço materializa as relações no decorrer do tempo, tornando-se então território.

O território é, portanto, materialização e espelho das relações sociais. Entendo que o tripé espaço, tempo e relações sociais tem seu elo neste último elemento.

Assim, a importância do uso deste conceito em si - e especialmente, ao trabalharmos com bairros rurais - está justamente no elo do tripé: nas relações sociais. Isto significa dizer que a compreensão das relações sociais no campo é a base para o entendimento do bairro rural.

Dito de outra forma: o campesinato entendido como classe social deste modo de produção é que permite a compreensão do bairro rural como uma unidade territorial. Mais do que isto: é a noção de pertencimento que têm os camponeses, concretizada por seu tipo específico de solidariedade ${ }^{3}$, que dá origem ao bairro rural.

Assim, a intenção deste artigo é mostrar como, através do trabalho camponês na terra, se constitui um bairro rural, numa perspectiva de que uma fração do território apropriada por meio de relações sociais não capitalistas adquire uma configuração particular, que, em especial no interior paulista, conhecemos por bairro rural.

O bairro rural que está sendo pano de fundo para esta abordagem é o Bairro Reforma Agrária, localizado nos municípios de Valinhos/Campinas, no interior do estado de São Paulo. Este bairro rural tem uma peculiaridade bastante grande, uma vez que é originário de um projeto de reforma agrária da década de $60^{4}$. Entretanto, inicialmente seu nome não foi este, o nome oficial dado ao assentamento foi Núcleo Agrário Capivari.

\footnotetext{
${ }^{3}$ Esta solidariedade camponesa é a expressão de sua “ordem moral”, a este respeito ver: (Bombardi, 2003). Ver também: Woortmann, 1990 e Sader e Pacheco, s.d.

${ }^{4}$ O Bairro Reforma Agrária foi fruto da aplicação Lei de Revisão Agrária promulgada no Governo Carvalho Pinto em 1960. Dentre as áreas destinadas à implantação da Lei esteve a Fazenda Capivari em Campinas que teve cerca de metade de sua área desapropriada e dividida em 72 lotes. Ver Bombardi 2004.
} 
O Processo de transformação de seu nome de Núcleo Agrário Capivari para Bairro Reforma Agrária é a própria revelação da constituição de um Bairro Rural. É o processo de transformação de um assentamento em bairro rural.

Este processo se efetivou em pouquíssimos anos: menos de dez anos após a implantação do assentamento. A formação do bairro rural se deu justamente por meio da teia de relações estabelecidas entre as famílias camponesas, como veremos.

Percebe-se atualmente, ao visitar o Bairro Reforma Agrária, que há um grande contraste entre a parte que foi desapropriada, onde é hoje o Bairro, e a outra parte da fazenda que não foi desapropriada, onde se vê praticamente apenas pasto.

Este contraste é um contraste entre unidades territoriais diferentes, pois produzidas por relações sociais diferentes: o Bairro é ocupado no duplo sentido - por cultivos e por pessoas. A própria concepção de ocupação da terra é diferente, faz parte da concepção camponesa o ocupar toda a terra. Há um senhor que conversando comigo e mostrando a área de seu sítio da qual ele "arrancou” o figo (que já tinha mais de trinta anos) e que, portanto, a terra estava "descansando", em pousio, falou: "Mas é feio a terra assim sem nada, né?”.

Ocorre que ao mesmo tempo em que a agricultura capitalista desenvolve-se, desenvolve-se também a agricultura camponesa, em um movimento contraditório, próprio do modo capitalista de produção.

Toda a contradição da sociedade em que vivemos se materializa no espaço, tornando-se território; assim, essa diferença entre a fração do território propriamente capitalista e aquela, fruto do trabalho camponês, se mostra através de contrastantes unidades territoriais.

O campesinato - ao contrário da idéia corrente - não vive de forma isolada, não só no tocante às relações que mantém com o mercado, mas também e, sobretudo, no que diz respeito às relações de parentesco e vizinhança:

As relações de vizinhança, porém, constituem entre a família e o povoado, uma estrutura intermediária que define o universo imediato da vida caipira, e em função da qual se configuram as suas relações sociais básicas... ${ }^{5}$

Essa teia de relações que ele estabelece não se dá "no ar”, ela acontece num espaço, tem um limite espacial. Desse modo, ela se territorializa e, portanto, tem sua expressão numa unidade em que fica perceptível uma certa "homogeneidade" de

\footnotetext{
${ }^{5}$ CANDIDO, 1987, p.58.
} 
territorialização (de uma maneira específica de construir seu “espaço” de acordo com uma concepção semelhante, entre os camponeses, de trabalho, técnicas, meio natural, família etc. - aquilo que chamamos de determinações culturais).

Em São Paulo, a essa unidade territorial camponesa, formada a partir da relação entre as unidades territoriais familiares (os sítios), chamamos bairro rural.

Qual a sua unidade de agrupamento? A freguesia, no conjunto, centralizada pelo que se costumava chamar de sua 'capital'? Não, certamente; mas sim aquelas unidades fundamentais referidas mais alto: os grupos rurais de vizinhança, que na área paulista se chamaram sempre bairro.

Este é a estrutura fundamental da sociabilidade caipira, consistindo no agrupamento de algumas ou muitas famílias, mais ou menos vinculadas pelo sentimento de localidade, pela convivência, pelas práticas de auxílio mútuo e pelas atividades lúdico-religiosas. As habitações podem estar próximas umas das outras, sugerindo por vezes um esboço de povoado ralo; e podem estar de tal modo afastadas que o observador muitas vezes não discerne, nas casas isoladas que topa a certos intervalos, a unidade que as congrega... ${ }^{6}$

Nice Lecoq Müller (1946, p.142), estudando os sitiantes paulistas, definiu o bairro rural da seguinte maneira:

O vocábulo designa qualquer conjunto de casas dispersas suficientemente próximas para que se estabeleçam relações entre seus habitantes. Não sendo propriamente uma unidade morfológica, pois que abrange várias formas de dispersão, o bairro é na realidade uma célula de comunidade social onde existem certos tipos de relações sociais a lhe darem corpo: laços de parentesco ou de vizinhança, reforçados freqüentemente pela existência de uma venda, capela ou escola cujo raio de ação marca comumente os limites do bairro... o pequeno proprietário sitiante, embora crie um povoamento disperso, está preso a uma certa unidade - o bairro - que corresponde a um certo fator geográfico que o torna distinto: a proximidade das casas e uma relativa concentração. Este fato é importante porque não se trata de uma dispersão em que o sitiante está isolado, em que suas relações com o meio só poderiam contar com recursos individuais...

Percebe-se que na definição de Müller a idéia de unidade e de relação são definidoras daquilo a que chama de Bairro Rural. Essa “unidade” à qual se refere a 
autora - unidade territorial construída a partir das relações que os camponeses estabelecem entre si - dá o caráter específico ao bairro rural e é responsável pelo sentimento de "pertencimento" que têm os camponeses que dele fazem parte. ${ }^{7}$

A noção de unidade é também central na definição apontada pela Prof ${ }^{a}$ Liliana Laganá Fernandes em seu estudo sobre o Bairro Rural dos Pires:

O elemento permanente, enfim, seria constituído pela existência de certa unidade entre um grupo de vizinhos, resultado da soma de determinados elementos de coesão, fazendo com que se estabeleçam contactos e intensa vida de relações, dentro de uma determinada área, a que o povo denomina de ‘bairro’... (Fernandes, 1971, p.7).

É justamente a unidade - que é em princípio social e que se transmuta em territorial - que proporciona o sentimento de "pertencimento" que os camponeses têm com relação ao Bairro Rural. Em um movimento dialético a unidade social forja a territorial e esta por sua vez concretiza a noção de pertencimento. E, novamente em contínuo movimento, o ciclo inicia-se a partir da noção de pertencimento: é esta que perpetua as relações sociais que se transmutam em territoriais.

Antonio Candido em sua obra Parceiros do Rio Bonito já apontou as pistas para a compreensão da noção de pertencimento como central na compreensão do Bairro Rural:

... - O que é bairro? - perguntei certa vez a um velho caipira, cuja resposta pronta exprime numa frase o que se vem expondo aqui: - Bairro é uma naçãozinha. - Entendase: a porção de terra a que os moradores têm consciência de pertencer, formando uma certa unidade diferente das outras... (Candido, 1987, p.65).

Esta certa “unidade” (e o uso desta palavra não é fortuito) que se diferencia das outras, é aquela com que determinado grupo camponês se identifica. Por isto falamos em identidade territorial. A identidade territorial vem, portanto, da unidade territorial e, novamente em movimento dialético: ao mesmo tempo em que a unidade territorial é informada pela identidade, esta forma e informa a unidade.

Maria Isaura Pereira de Queiroz em seu artigo "Bairros Rurais Paulistas” definiu o Bairro Rural da seguinte maneira:

Era o bairro rural um grupo de vizinhança de 'habitat' disperso, mas de contornos suficientemente consistentes para dar aos habitantes a noção de lhe pertencer, levandoos a distingui-lo dos demais bairros da zona. O ‘sentimento de localidade’ constituía

\footnotetext{
${ }^{6}$ Ibid., p.62.

${ }^{7}$ No Bairro Reforma Agrária, por exemplo, os camponeses referem-se a ele como "aqui no Reforma”.
} 
elemento básico para delimitar a configuração de um bairro, tanto no espaço geográfico quanto no espaço social...

O bairro rural é ao mesmo tempo um tipo de povoamento e um tipo de grupo social antigo e persistente, que atravessou séculos mantendo-se semelhante à si mesmo: não terá persistido até nas zonas de povoamento recente, como padrão clássico de povoamento brasileiro, ao nível dos pequenos empresários agrícolas? (Queiroz, 1967:65,110-111).

O bairro rural se configura, assim, como a expressão da identidade territorial de um grupo de sitiantes ${ }^{8}$ (camponeses) que através do trabalho familiar transforma o meio natural, ou um território anterior, por meio de padrões culturais ${ }^{9}$ estabelecendo uma rede de relações entre si que cria uma especificidade no território, que se caracteriza, por exemplo, através do tamanho semelhante dos sítios, de tipos de cultivo em comum ${ }^{10}$, de técnicas de trabalho semelhantes, da semelhança na organização interna dos sítios etc.:

recapitulemos analiticamente os elementos apontados mais alto como integrantes do conceito de bairro, começando pela base territorial, essencial à sua configuração... Mas além de determinado território, o bairro caracteriza-se por um segundo elemento, o sentimento de localidade existente nos seus moradores, e cuja formação depende não apenas da posição geográfica, mas também do intercâmbio entre as famílias e as pessoas, vestindo por assim dizer o esqueleto topográfico... (Candido, 1987, p. 64 -5).

\footnotetext{
${ }^{8}$ Cabe aqui o conceito de sitiante, segundo Müller (1946, p.5, 6 e 8) o definiu: “...sitiante é todo o pequeno produtor rural que, responsável pela lavoura, trabalha direta e pessoalmente com a terra com a ajuda de sua família e, ocasionalmente, de alguns empregados remunerados... podendo esta (a terra) ser propriedade dele ou não... A distinção com o fazendeiro, quanto mais não fosse por este contar com uma produção muito maior, ficaria óbvia pelo fato de, em regra, não trabalhar ele pessoalmente a terra, ficando na posição de simples administrador, contando não com alguns, mas com muitos empregados assalariados... Para que um proprietário seja sitiante, não parece pois influir o número de alqueires que possui; o que importa é o caráter de sua exploração do solo que, quando ficam dentro dos característicos do sitiante, faz com que seja considerado como tal. Assim sendo, um sítio pode abranger a pequena, a média ou mesmo a grande propriedade, embora não seja errado afirmar haver maior incidência deles dentro da primeira categoria...”.

Vale dizer que trabalho em uma concepção em que sitiante e camponês estão são sinônimos. Na verdade, o sitiante, no interior de São Paulo é o camponês proprietário, assim, sitiante é uma das formas de campesinato, o camponês pode também ser parceiro, posseiro e rendeiro.

${ }^{9}$ Sobre a influência dos padrões culturais na "paisagem”, segundo Müller (1946, p.13): “...Isso tudo se traduz em novos gêneros de vida e em novas paisagens, quer pela possibilidade, com outras técnicas, de diferentes aproveitamentos dos recursos naturais. Pela aceitação de parte do que encontraram ou influência sobre as populações que aí viviam antes de sua chegada, o colono traz uma modificação parcial, nas regiões de colonização estrangeira mais intensa, dos gêneros de vida e paisagens que já estavam estabelecidos, ou que provavelmente se estabeleceram dentro dos moldes da cultura cabocla se não tivessem produzido esses contatos...”
} 
Numa abordagem geográfica de bairro rural, a base territorial, que Antonio Candido afirmou ser essencial em sua configuração, não é apenas o suporte, o esqueleto, para as relações entre as famílias, mas é determinante do tipo de relação que elas terão com o meio natural. De qualquer forma, no caso do bairro rural, as relações estão concretamente (no sentido literal do termo) ligadas ao espaço - em função do trabalho na terra - daí a base territorial ser elemento fundamental.

Assim, o bairro não é a soma de sítios, mas a relação que se estabelece entre essas diferentes unidades camponesas e delas com a escola, com a venda, com o centro comunitário etc.

Dessa forma, o bairro rural se configura como uma unidade territorial geográfica - a partir da identidade territorial -, num entendimento de que se caracteriza como uma fração do território (diferente daquela produzida diretamente pelo capitalismo) que é resultado da articulação das unidades camponesas, que por sua vez, são determinadas pela liberdade e autonomia camponesas via o controle do tempo e do espaço, não só o de moradia, como e, sobretudo, o de trabalho.

A especificidade do campesinato como classe social portadora de uma ordem moral, que se opõe à ordem econômica, é que permite a existência do bairro rural, desta unidade/identidade territorial.

Certamente a identidade territorial só é possível de existir em função da peculiaridade da produção camponesa: produção esta informada por sua ordem de valores que por sua vez, ao mesmo tempo, informa sua maneira de produzir ${ }^{11}$.

Assim, essa unidade geográfica caracteriza-se por ser mais “justa” do ponto de vista social: o campo, nesse caso, é “ocupado”, no duplo sentido - por cultivos e por pessoas.

Dessa maneira, é possível falar em uma unidade/identidade geográfica, fruto da fração do território que é criado a partir do trabalho camponês, ou seja, se o território é entendido como o resultado da inter-relação entre tempo, espaço e relações sociais, e, se nesse caso, tempo e espaço são determinados por um tipo de relação que se fundamenta na lógica camponesa, então ele adquire um "aspecto", ${ }^{12}$ uma configuração,

\footnotetext{
${ }^{10}$ O Bairro Reforma Agrária se caracteriza, nesse sentido, por ser produtor de frutas, especialmente uva, goiaba e figo.

${ }^{11}$ Ver Bombardi, 2003.

${ }^{12}$ Sobre o contraste fruto da agricultura capitalista e da agricultura camponesa: "Chama nossa atenção de geógrafos, a existência de grandes campos circulares, divididos em quadrantes, cada qual homogeneamente semeado com soja, milho, arroz, feijão, resultado de uma agricultura altamente tecnificada, a alguns quilômetros de outros, com formas irregulares, onde uma cultura consorciada de
} 
que é a do bairro rural. Os sitiantes se reconhecem uns aos outros por meio dessa identidade, ou seja, não é o tamanho da propriedade que indica quem é ou não sitiante, mas o modo de vida que nela se dá, que se plasma no espaço, transformando-o em uma fração diferente do território, que pode até mesmo ser apreendida com o olhar.

Assim é que, ao conversar com os camponeses do Bairro Reforma Agrária, eles autodenominam-se "sitiantes”, ou seja, essa palavra expressa seu modo de vida, e, nesse sentido, eles não falam “o meu lote”, 13 e sim, o meu sítio.

Isso significa que, no caso do Bairro Reforma Agrária, ao construírem uma fração de território camponesa, onde antes era um território capitalista, eles territorializam uma outra forma de vida, a da lógica camponesa. Assim, como já foi afirmado anteriormente, o lote se transforma em sítio e o assentamento em bairro rural. $^{14}$

Ao virem para suas terras, quando assentadas, as famílias trouxeram os cultivos que já realizavam anteriormente. A maior parte das famílias era oriunda das decadentes fazendas de café do entorno, assim, em geral cultivavam gêneros como algodão e alguns legumes.

Poucas das famílias assentadas dedicavam-se ao cultivo de frutas. Entretanto, com o passar dos anos, as demais famílias foram também cultivando frutas em suas terras a partir da troca de experiência com aquelas que já as cultivavam.

Ao perceberem que as frutas possibilitavam auferir maior renda da terra, as demais famílias foram substituindo os cultivos que faziam por estes: o do figo e o da uva.

Tal substituição de cultivos se fez através do contato estreito que os camponeses têm entre si, um vizinho ensina o outro. E a palavra vizinho no bairro rural não significa, como na cidade, aquele que está “encostado” ou próximo, vizinho é qualquer um dos sitiantes do mesmo bairro rural, ainda que em uma distância significativa:

arroz, feijão, milho e mandioca, se mescla a árvores nativas de grande e médio porte, numa aparente desordem, sem que haja parcelas específicas para cada produto. São distintos sistemas de cultivo, que implicam em organizações sociais específicas, acompanhadas de técnicas e práticas culturais também específicas” (Sader, R. \& Pacheco, R., s.d., p.1).

13 Palavra utilizada nos documentos do Estado sobre o Bairro Reforma Agrária e na própria Lei de Revisão Agrária, responsável pela origem do Bairro.

${ }^{14}$ Bernardo Mançano Fernandes, durante o I Simpósio de Geografia Agrária, realizado no Departamento de Geografia da Universidade de São Paulo nos dias 27, 28 e 29 de maio de 1998, fez menção a esse processo de transformação de assentamentos em bairros rurais. 
Ah, quem me incentivou a plantar serigüela foi o Zeolo... é vizinho aqui, a gente tem pouca, porque a terra não é dentro da área nossa, fica do lado de lá da cerca, né? Mas como aquelas terras estão abandonadas, eu comecei cultivar, plantar uma coisa e outra, aí o Zeolo [o vizinho] falou para mim: 'por que você não planta serigüela?'.... ${ }^{15}$

A expressão "vizinho” revela uma relação e um tipo de prática que é social, específica da sociabilidade camponesa à qual os antropólogos chamam de solidariedade vicinal.

Há uma prática de solidariedade que é básica no campesinato, em que a generosidade e a troca de favores dão o direcionamento da vida social:

... quando a gente morava nas Três Vendas a minha mãe tinha a base de 150, 200 galinhas... e a minha mãe gostava bastante, e tinha lugar, espaço para as galinhas botarem... a danada da Velha conhecia... quando chegava lá tinha, uma família de patrício que morava lá falava: 'ê, $d$. Rosa, achei uma ninhada, aí tem 15.' Aí a minha mãe falava: 'Então você pega a metade para você e metade você traz aqui.' Daí ela pegava e trocava com linha, botão, essas coisas, e quase todos os dias vinha galinha com $13,12,11 . .{ }^{16}$

Notável que a prática da solidariedade sustenta a vida camponesa, a ajuda e a troca de favores dão respaldo à família nos momentos de adversidade.

Uma das grandes expressões do significado concreto e real do que é o bairro rural é o acompanhamento da alteração dos cultivos.

Nos úlitimos anos, o cultivo de goiaba praticamente se difundiu no Bairro Reforma Agrária. Quem introduziu o cultivo da goiaba no Bairro foram as famílias japonesas:

Sr. Tanaka:...o japonês plantou uva Itália, mas aqui dá, mas muito difícil, o clima num ajuda, né? Então goiaba, pra mim goiaba é melhor, eu achei naquele tempo, tem que podar também, né, mas uva, pêssego, figo, poda na época certa mesmo, colhe, uma vez por ano, esse uva também, se perder esse ano, por exemplo, de chuva de pedra, de geada, essas coisa, acontece, né, aí perde esse ano, já perde tudo mesmo, aí tem que fica parado um ano, aí, mas essa goiaba quando poda aqui em Campinas, poda quase ano inteiro, mexendo e brotando, mexendo quase ano inteiro... por isso que eu plantei, mas agora, naquela época goiaba num tinha, tinha pouca goiaba, mesmo aqui na

\footnotetext{
${ }^{15}$ Entrevista com sr. José Brito, realizada em 10 de fevereiro de 1999.

${ }^{16}$ Entrevista com sr. Luís Antônio Chiquetano, realizada em 19 de outubro de 1999.
} 


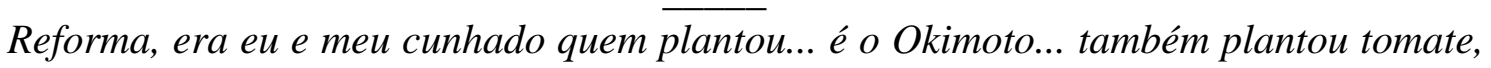
pêssego, nectarina, essas coisa, mas eu achei goiaba melhor pra aqui, era antigamente D. Therezinha: Mas depois de uns anos aqui, a turma... um monte rancou o figo $e$ plantou goiaba.

Sr. Tanaka: Agora é arrancando o figo, uva, e plantando...

D. Therezinha: Cê vai ver, daqui um tempo, uns anos, o figo vai dar mais dinheiro que goiaba... ${ }^{17}$

Este cultivo foi introduzido justamente em função do contato das famílias japonesas do Bairro com famílias de origem japonesa do bairro rural vizinho, o Macuco:

Larissa: Ah, a goiaba aqui começou como? Alguém começou?

Sr. Arlindo: Não, já tinha japonesada no Macuco, são veterano, né? Tem cinqüenta anos de japonês de goiaba lá... O Luís tem pé de 48 ano, né, Vânia? Ele falou pra mim que o pai dele plantou. Tá dessa grossura assim os galho, né? Assim ó... [Ele mostra com as mãos a espessura. $]^{18}$

O cultivo da goiaba surge como uma possibilidade dos camponeses extraírem renda de monopólio com a venda da fruta na época da entressafra natural. Por meio da poda da goiabeira no decorrer de todo o ano e da irrigação da mesma no período da seca (de abril a setembro) os sitiantes conseguem garantir uma colheita durante todos os meses. Assim, há uma época do ano (o inverno) em que há pouquíssima goiaba disponível no mercado e dessa forma ela atinge um preço elevado.

Os cultivos novos que são introduzidos no sítio são aprendidos com vizinhos que já o fazem:

Depois que a gente partiu pra goiaba, tamo com ela até hoje... vai fazer 12 anos... ah, a gente resolveu mudar porque o produto do figo, ele é um produto muito caríssimo, também pra trabalhar, né? E chegava nessa época assim, época de enchente, é difícil, né, Landa? Época de chuvarada, então num dava muito, e fora de época também a gente num... tempo bravo, porque a gente tirava figo fora de época, comecemo tirar uns quatro anos, uns dois anos deu certo, foi bem, mas depois de dois anos começou vim, né Landa, temporal fora de... granizo, essas coisa, porque a gente tem muita despesa também, né? Então a gente partiu pra goiaba... ah, naquela época quem que a gente

\footnotetext{
${ }^{17}$ Entrevista com sr. Tanaka e d. Therezinha, realizada em 01 de dezembro de 1998.

${ }^{18}$ Entrevista com sr. Arlindo Camilotti, realizada em 14 de outubro de 1998.
} 
conversava? Era muito pouco desenvolvido, era mais japonês que começou, mas aí foi o Angelim, né? O Angelim Scabello, ele veio aqui, aí ele deu uma força pro meu irmão, vendeu as muda, né, aí o meu irmão pagou, ele veio enxertar... foi ele que forneceu a muda pra nós, foi ele que veio enxertar... ${ }^{19}$

Pela questão de proteção ao grupo étnico, demorou um certo tempo até que o cultivo da goiaba se disseminasse, houve uma certa resistência das famílias de origem japonesa em ensinar às outras as técnicas necessárias ao cultivo. Entretanto, quando a relação era estreita entre essas famílias e outras de origem não japonesa, elas transmitiam seu conhecimento:

Se esses daí não fosse, que italiano o sr. sabe que é teimoso, né? Se eles não fosse teimoso, quando o japonês ali do lado, que sempre morou viznho com nós aí, falou há 15 anos atrás, isso que eu lembro, que nós sofremos pra plantar uma uva, que não queria que plantasse uva, eles queria que plantasse goiaba, cê vê que é difícil, hein, é difícil japonês tá num ramo e ele falar pro outro plantar a mesma coisa, eles nunca fala que dá, mas a mulher do seu Morita, e o seu Morita também... da boca dele eu nunca ouvi não, mas a d. Luísa falava pro meu sogro: 'Ai, seu Antônio, não planta uva não, planta goiaba, goiaba dá bem'. Se aquela época nós planta, o sr. vê, 15 ano, dois ano que leva pra dar, né, um ano que planta, um ano que enxerta, no ano seguinte tá dando, então era treze anos que nós tava colhendo goiaba. ${ }^{20}$

Paralelamente, por vezes há uma recusa em implementar um outro cultivo no sítio justamente pela questão do costume cultural. Ouvi no trabalho de campo a seguinte declaração:

... em 85 nós comecemo a querer plantar, aí num decidia muita coisa não porque aquele tempo lá o meu pai que mandava e ele falava que goiaba era só pra japonês, que nós num tinha paciência pra... italiano num tinha paciência pra trabalhar com goiaba, a d. Luísa falava: 'Não, seu Antônio, o sr. Planta...', aí foi indo, foi indo, foi indo, depois que o meu pai ficou doente aí que nós resolvemo plantar mesmo... ${ }^{21}$

A resistência em passar o conhecimento para as demais famílias parece advir da consciência de que a partir do momento em que o cultivo da goiaba - com a nova técnica introduzida pelos japoneses - se disseminasse, haveria uma redução ou ausência da renda de monopólio, como de fato parece estar acontecendo:

\footnotetext{
${ }^{19}$ Entrevista com Marlene Cachefo, realizada em 20 de janeiro de 1999.

${ }^{20}$ Entrevista com d. Maria Aparecida Rodrigues Chiquetano, realizada em 10 de novembro de 1998.

${ }^{21}$ Entrevista com sr. Luís Antonio Chiquetano, realizada em 19 de outubro de 1999.
} 
Mas agora negócio aí, é muita produção, né? Aqui nessa região goiaba tá empesteado, Minas tá empesteado... Nossa, em Minas tão plantando goiaba que dá até medo! No Paraná tá plantando goiaba, aqui pro lado de Registro tão plantando, que diz que tem, de primeiro a turma plantava era muito chuchu, banana, né, a turma tá plantando goiaba agora, então tá muita produção [A deles também dá na mesma época?] Quase tudo dá no mesmo tempo, que agora a turma tá podando tudo esparcerado, eu podo um pouco, o outro poda um pouco, o outro poda um pouco, então quando eu tenho pouco, todo mundo tem, então vai indo ajunta e aí dá bastante, e quando chega no enchente no mesmo, aí, nossa, aí ninguém quer... vender vende, né? Mas aquele preço! ${ }^{22}$

A fala anterior, que é também reveladora da apropriação da renda da terra pelo capital comercial, demonstra que o preço da goiaba está bastante definido pela oferta e procura, mesmo na época do ano que não é a da safra natural da goiaba.

Assim, nota-se que os cultivos, bem como as técnicas utilizadas, vão sendo introduzidos conforme os sitiantes percebem que com um "vizinho funcionou”. Esse vizinho, por sua vez, aprendeu com um parente ou algum amigo de outro bairro rural.

... É aqui pra, ali em cima do Zeolo sempre tem, ele sempre tem serigüela, e aqui tem também, o homem do bar também tem aí, eles têm também... é, a gente vai falando de um pro outro, tem que pegar as coisas que dá mais, né... ah, é melhor, né [ter mais variedade] porque a sra. ganha mais, tem mais mercado pra vender. Que a sra. Sabe, o único que não pode é parar de colher, né? Se parar de colher, aí complica, né? Porque cê não ganha dinheiro, lavoura, se não ganha dinheiro, não vai, né? ${ }^{23}$

$\mathrm{Na}$ fala seguinte esse processo de observar o resultado obtido por um vizinho e depois decidir pelo cultivo da fruta fica bastante claro:

Ah, faz tempo... mais ou menos que ela está plantada aí deve fazer uns oito anos, mais ou menos... [Por que o sr. resolveu plantar a serigüela?] Por quê? Por que... é difícil falar para você porque, viu? É que a gente vê alguém que, geralmente uma pessoa só planta um tipo de cultura ou vendo outro que já tem, né? E como é que vai indo mais ou menos aquilo e então a partir daí ele vai plantando também, né? E o outro vai copiando da gente também, né? É uma corrente, né? Desde que se alguém fizer uma planta e

\footnotetext{
${ }^{22}$ Entrevista com sr. Luís Antônio Chiquetano, realizada em 04 de agosto de 1999.

${ }^{23}$ Entrevista com sr. Antônio Pavanelli, realizada em 11 de fevereiro de 1999.
} 
aquela planta for ruim ninguém, vai querer plantar ela, né? Aonde se torna como está a goiaba hoje, né? É, todos quiseram plantar goiaba, né? ${ }^{24}$

É fundamental a expressão utilizada por este sitiante, ela é reveladora do siginificado do Bairro Rural: é uma corrente. A corrente revela ao mesmo tempo o sentido de elos, ou seja, de ligação, de unidade e, também, o sentido de continuidade, de passagem de um ao outro: de um ciclo que se perpetua.

O conhecimento é sociabilizado pelos vizinhos que vão transformando suas unidades territoriais (sítios) e o Bairro vai alterando sua configuração. Quando um novo cultivo bem sucedido é implantado, novamente é socializado e os sítios são transformados, um movimento contínuo que se perpetua ao longo dos anos.

A possibilidade de escolha do cultivo a ser implantado na terra é em si reveladora da condição de autonomia camponesa: não só do tempo, mas, especialmente neste caso, também do espaço. O bairro rural em si mesmo é a concretização da autonomia camponesa.

Esta autonomia também diz respeito à relação que o camponês estabalece com o mercado, ou seja, os cultivos são escolhidos em função de “driblar” a subordinação da renda camponesa ao capital ou ainda na tentativa de auferir a renda de monopólio.

Por isto também o conceito de bairro rural como unidade/identidade territorial é tão importante, pois é possível compreender a territorialização camponesa em toda a sua amplitude, o que significa dar conta do papel do campesinato em sua inserção no modo capitalista de produção.

Voltando ao cultivo da goiaba, a possibilidade de auferir renda de monopólio através deste está associada à colheita no período de entressafra, o que só é obtido por meio da irrigação, ou seja, consegue-se colher o fruto durante o ano todo.

Com esse mesmo objetivo, de modo a possibilitar a extração de maior renda da terra, é que no cultivo de uva foi sendo introduzida a chamada "poda verde", ou seja, normalmente a uva é podada nos meses de inverno (julho e agosto). Entretanto, alguns sitiantes (ao que tudo indica, através do contato com sitiantes da região de Itaici, em Indaiatuba) introduziram a poda no verão (no tempo das águas), o que faz com que a colheita se dê a partir de março. Dessa forma, a fruta alcança um alto preço no mercado, justamente pela inexistência da oferta, o que determina que quem quer uva em uma

\footnotetext{
${ }^{24}$ Entrevista com sr. Nelson Frates, realizada em 17 de março de 1999.
} 
época que não é a de sua safra deve pagar por isso, o que se configura como renda de monopólio: “Ah, a gente decidiu fazer essa coisa aí todo ano, né? [a poda verde] A que dá [uva] do tempo não sobra nada, então vamos tentar fazer outra coisa... não, podei uma parte só... mês de abril, maio...". 25

A poda em uma época não usual faz com que a planta fique mais suscetível a doenças em função da chuva, o que significa que os gastos no trato da plantação serão mais elevados, e também a durabilidade da videira diminuirá sobremaneira. Dessa forma, a escolha desse tipo de poda também depende da capacidade financeira da família camponesa de arcar com um gasto extra, de tal forma que depois possa obter a renda de monopólio.

Assim, algumas técnicas são introduzidas nos cultivos de tal forma que a época da colheita seja realizada em um momento que há baixa oferta de fruta no mercado:

Se você podar embaixo, aí perde a safra inteira... é, a gente poda em cima, se caso der uma zebra, aí a gente poda embaixo, aí se perder, muitas vez num recupera o 100\%, mas já dá pra sair algum pouco, né? Mas se perder, podar embaixo e perder... [Por que poda embaixo? Quando?] É julho, começo de agosto, pra sair uma brota bonita o certo seria em agosto, né? Mas como a gente é meio ganancioso, é, tudo vai da gente querer ganhar mais, né? Então poda um pouco mais cedo, mas é arriscado [Se fosse podar em agosto, não podaria onde o sr. está podando?] Não, a gente poda embaixo, que a uva só tem que podar embaixo, na coroa, no primeiro olho de baixo, isso aí é invenção, faz pouco tempo que a turma tá inventando isso aí, então num pode podar ela em cima, cê tem que podar ela em cima, mas depois logo cê tem que voltar podar embaixo, assim que ela terminar, cê poda embaixo, pra depois ela ficar sempre embaixo mesmo... assim, fim de novembro, já começa a colher... muitas vez poda e pra ter certeza mesmo, passa um veneninho nela pra puxar ela um pouco, né? Pra ela sair, mas também num pode passar forte, que ele murcha ela... Essa eu podei no meio, nós fizemo um teste de podar no meio pra ver o que que vai dar, né? [O que é 'no meio'?] É, podou no segundo arame, né, e agora era pra ter podado embaixo, mas nós queria tirar ela mais um dia adiantado, né? Que o ano passado colheu bastante, o ano trasado colheu bastante, num fez muito dinheiro por causa que o preço tava barato, o ano passado num fez também nada porque colheu um bom pouco, mas também saiu tudo na

\footnotetext{
${ }^{25}$ Entrevista com sr. José Brito, realizada em 10 de fevereiro de 1999.
} 
enchente, num deu, esse ano aqui resolvemo podar um pouco mais cedo, pegar umas quinhentas caixa mais cedo, pegar uns quatro real a mais, né?

Se após o período do Natal a oferta de uva é grande no mercado, antes dele e durante o "período das festas” há grande procura por uva e baixa oferta, o que determina um preço mais elevado da fruta. Assim, essas técnicas são adotadas de modo que boa parte da colheita possa ser feita antes das festas. Vê-se que, para tanto, além da poda, um produto químico é utilizado, o cálcio, de forma que a colheita possa ser realizada mais cedo.

Para o cultivo do figo e da serigüela é utilizado um produto químico que tem a função de amadurecer as frutas em um curto espaço de tempo. O seu uso permite que a época da colheita seja pré-determinada e que todos "os frutos não saiam ao mesmo tempo", ou seja, o processo natural em que a produção de frutos se concentra em um curto período de tempo determinaria a necessidade de um excesso de mão-seobra e um provável baixo preço das frutas:

... serigüela parece que tem 32 pés, mas é bastante, né, a sra. sabe, ela é uma plantinha muito, não sei se a sra. já viu a embalagem de moranguinho... é igual, embala igual, então tem que embalar tudo certinho, ah, demora, viu! Ish... pra sra. embalar cinqüenta caixinha, vai quase o dia inteiro, demora porque tem que acertar tudo em carreirinha, tudo certinho, aí depois a sra. tem que participar, é difícil... essas tá mandando pra São Paulo... vende, até... [bastante] é doce, a turma come, pode fazer suco também... a sra. Sabe, comecemo mandar agora, acho que não veio fatura ainda, não sei como que tá o preço... faz dois anos que nós plantemo, mas começou produzir agora, esse ano... agora, pra gente antes de colher tem que passar o Trel, né?... É um remédio que a gente passa pra ela madurar, né, se a sra. for deixar tudo no tempo mais ou menos em março que ela começa a madurar, né, aí não dá tempo, né, aí não vence porque aí amadura tudo de uma vez... passa o Trel uns três, quatro pés, depois colhe aquele pé, depois passa mais uns três, quatro, até o fim, né? Ela não é que nem a uva, né, a uva sabe, a sra. pode deixar no pé, ela não pode, né? Ela madurou, ela cai, ela ficou mole já não serve mais pro comércio, né? Tem que colher quando tá começando a madurar... 26

... pena que não tá madura pro cê ver, é que nós tinha passado produto pra ela amadurecer e tava colhendo, né, aí eu parei por causa do carnaval, entendeu? No carnaval sabe como é que é, né? Não tem preço, não vende, é só baqunça, aí eu parei 
de passar, agora só vou passar a semana que vem, cê passa, dali dois dias ela amadurece... é rápido, porque você não pode deixar amadurecer normal, que aí cê não colhe, ela bicha tudo, entendeu ? $^{27}$

$\mathrm{Na}$ fala anterior meu interlocutor está falando da serigüela que introduziu há pouco tempo em seu sítio. Através do uso do referido produto químico é possível controlar a colheita de forma que a família consiga colher o máximo de frutos e também contornar épocas em que o preço seja muito baixo. Também o surgimento da serigüela no Bairro se deu por meio da troca intensa de informações com parentes:

Larissa: E quem ensinou vocês a plantarem serigüela?

Alzira: Era o meu cunhado... A serigüela não era conhecida, algum tinha algum pé, então o meu cunhado morava aqui, então ele mudou lá na chácara do seu... lá em Valinhos, uma chacrinha lá pro lado de Valinhos, e lá tinha uns pés, acho que tinha quanto, uns cinco ou seis pés, e o sogro dele diz que catava assim, derrubava, não catava nada porque não existia, não sabia também, né? E ele catava e vendia assim, né, acho que no mercado essas coisa... novidade, daí ele mudou lá, daí eles faziam a mesma coisa, então começou plastificar, mas plastificar em casa sem máquina, e tal, só passar o plástico, e daí foi, foi, que depois começou a sair Etrel, daí começaram a fazer teste no Etrel e começou a sair, aí deu certo, aí começaram a plantar mais, daí ele deu muda pra nós.... é, deu pouquinha, né, daí nós plantou, depois nós cortemo o pé pra plantar mais... então foi assim, fomos formando devagar, no meio do figo, depois quando ela foi, fomo tirando o figo, e ficou assim. ${ }^{28}$

A expansão do cultivo da fruta no Bairro, que foi introduzido há aproximadamente 14 anos (a família da fala anterior foi a primeira a introduzir o cultivo no Bairro, as demais aprenderam com ela) está relacionada à possibilidade de evitar que parte da renda da terra seja apropriada pelo capital industrial. O cultivo dessa fruta não exige grandes despesas com insumos químicos, nem adubos, nem venenos, por isso ele é considerado vantajoso por algumas famílias: “a senhora sabe que é uma planta boa, uma planta que não dá muito, a senhora não precisa passar veneno, não precisa por esterco, não precisa por nada... só que ela dá uma vez por ano só”. ${ }^{29}$

\footnotetext{
${ }^{26}$ Entrevista com sr. Antônio Pavanelli, realizada em 11 de fevereiro de 1999.

${ }^{27}$ Entrevista com sr. Antônio Bregion, realizada em 11 de fevereiro de 1999.

${ }^{28}$ Entrevista realizada em 04 de março de 1999.

${ }^{29}$ Entrevista com sr. Antônio Pavanelli, realizada em 11 de fevereiro de 1999.
} 
Nos primeiros anos em que a serigüela foi introduzida no Bairro, de fato não demandava nenhum investimento em insumos químicos. Entretanto, conforme começou a ser disseminada, esse quadro se alterou:

Alzira: Na serigüela [a gente] passou um pouquinho [de veneno] esse ano, mas até outro dia nós não passava nada, agora passaram por causa de um bichinho que tava roendo... ${ }^{30}$

Evitar gasto com "veneno" no cultivo reduz de forma significativa a extração de parte da renda camponesa. Ainda que dependam de um produto químico para terem controle do processo de amadurecimento da fruta, esse gasto é muito menor do que o que se tem em qualquer dos demais cultivos de frutas que se faz no Bairro.

De qualquer forma, a expansão ou não de um determinado cultivo não está apenas associada à questão da renda da terra. Há, como vimos, resistências culturais que podem retardar ou mesmo evitar que um ou outro cultivo seja introduzido em determinado sítio.

A serigüela é uma fruta nordestina que alguns até mesmo conheciam e tinham um pé junto a outras árvores frutíferas:

... essa frutinha aqui é lá pro lado do Nordeste, pra esses fundão aí, entendeu? É, quer dizer, lá é a terra dela, assim... Então, eu tinha um pé disso aqui há uns 15 ano atrás, ali, ele era grandão, mas dava que dava medo! Só que nós não conhecia direito, sabe, não sabia que, comia tudo, mas não sabia que isso aqui tinha comércio entendeu, se eu soubesse, naquele tempo lá nós já tinha formado, aí, nossa! Depois que começou formar, começou ganhar dinheiro com isso aqui, né? A ter comércio, né? Agora já tá começando, como se diz, já tá começando a ter bastante, né? Cê ganha dinheiro quando não tem, se é poucos que tenha, né? Se vai todo mundo plantar, é que nem uva, né? Tá carregado... é porque quando começou a mandar aí, começou a aparecer no mercado, porque antes não tinha no mercado aqui, entendeu? Então era de fora também isso aí, né? Sei lá, aos poucos a turma começa a perceber... ${ }^{31}$

O processo da determinação da maior parte das frutas pelo mecanismo da oferta e procura é extremamente claro para os sitiantes. Eles têm a exata noção de que é possível auferir uma renda maior com determinado cultivo quando a oferta no mercado é baixa. Assim, enxergam que, como aconteceu com a uva, a tendência é

\footnotetext{
${ }^{30}$ Entrevista realizada em 04 de março de 1999.

${ }^{31}$ Entrevista com sr. Antônio Bregion, em 11 de fevereiro de 1999.
} 
acontecer com a serigüela também, ela ainda “tem preço” porque sua oferta é pequena no mercado.

Assim, em função da origem da fruta, pude escutar no trabalho de campo de tratar-se a serigüela de uma fruta alcaíde, palavra que eu não conhecia e para qual encontrei o seguinte significado no dicionário: "De baixa qualidade ou categoria... mercadoria que não se vende... objeto velho, imprestável ou fora de moda...”, 32 o que parece demonstrar que do mesmo jeito que italiano não tem "paciência para cuidar da goiaba”, não lhe é apropriado cultivar uma fruta nordestina.

Nos últimos anos, sobretudo de quatro anos para cá, o cultivo do figo tem diminuído muito no bairro, fato que parece estar associado a uma doença provocada por um inseto ao qual chamam de "mosca do figo", que teria possivelmente sido inserida no Bairro através de mudas do figo gigante, trazidas da Turquia por um grupo ligado à prefeitura de Valinhos, composto principalmente de agrônomos.

Os sitiantes foram procurando formas de lidar com tal inseto, seja através da orientação de agrônomos da Casa da Agricultura, ou da empresa da qual compram os insumos (através da indústria fabricante de tais produtos, como a Bayer, por exemplo), seja através de experiências que eles mesmos procuram desenvolver. De qualquer forma, as técnicas que julgam bem sucedidas rapidamente espalham-se pelo Bairro de modo que, em um curto espaço de tempo, todos a estão empregando, como por exemplo, a inserção no meio da lavoura de figo de uma garrafa plástica com restos de frutas em decomposição de forma que as moscas entrem na mesma, por pequenos orifícios, e não consigam sair depois. Assim, há uma grande homogeneidade no bairro rural quanto ao que é cultivado e como é cultivado.

É possível notar como se dá a constituição de uma unidade territorial, de como se plasmam de forma tão clara os elementos constitutivos do território: o tempo, o espaço e as relações sociais ${ }^{33}$.

O bairro rural deve, portanto, ser concebido como uma unidade territorial na perspectiva de que ele adquire uma caracterização homogênea: funciona como um todo, como uma unidade. Ou seja, as alterações que se processam em uma unidade camponesa, se bem sucedidas, vão se alastrando pelo bairro como um todo, de

\footnotetext{
32 Dicionário Brasileiro da Língua Portuguesa, 1982.

${ }^{33}$ Para maiores detalhes ver: (Bombardi 2004).
} 
tal forma que, por meio das relações interpessoais, ao cabo de poucos anos seus cultivos predominantes se transformem.

Evidentemente tal alteração nos cultivos se processa em um bairro rural como o Reforma Agrária, onde seus camponeses produzem quase que exclusivamente para a comercialização de suas mercadorias. Maria Isaura Pereira de Queiroz, em seu trabalho sobre bairros rurais, fez a seguinte observação (1967, p.113):

A existência de um bairro como o Taquari, - que é bairro rural, mas que não mantém mais a economia de subsistência tradicional nos bairros caipiras, - faz-nos distinguir duas modalidades diferentes desse tipo de agrupamento social: o bairro rural tradicional, que é composto de camponeses, ou melhor, cujos habitantes vivem num regime econômico primordialmente orientado para a subsistência; e o bairro rural moderno, que é composto de agricultores, isto é, cujos habitantes vivem num regime econômico orientado para a comercialização dos produtos agrícolas. À parte esta diferença de economia, num e noutro tipo de bairro as relações sociais básicas entre as famílias e os indivíduos são as mesmas.

Nesse trabalho, como foi afirmado anteriormente, a concepção de camponês adotada é diferente desta apontada por Maria Isaura. Há aqui o entendimento de que seja o agricultor um produtor de mercadorias quase que exclusivamente voltadas para a comercialização ou, ao contrário, que se dedique quase exclusivamente aos cultivos destinados à subsistência da família. Não é esta característica que o define como camponês ou não, essa definição está mais associada ao trabalho familiar e ao baixo ou inexistente emprego de mão-de-obra assalariada e ao controle da unidade feito pela família, do que ao destino daquilo que é produzido no interior da unidade.

De qualquer forma, depreende-se da observação que faz Maria Isaura que independentemente da estreiteza ou não que o sitiante tem com o mercado, a teia de relações que ele estabelece, constituindo o bairro rural, não se altera.

Assim, a relação entre os sitiantes é de tal forma intensa no bairro rural, que os problemas coletivos são também resolvidos de forma coletiva. É o que se pode perceber, por exemplo, no episódio em que faltou chuva por um determinado período de tempo passando a prejudicar a lavoura da maioria dos sitiantes. As famílias então reuniram-se e fizeram uma procissão. Há uma fala no terceiro capítulo que relata esse acontecimento. Pude, entretanto, colher outras, o que revela que o evento tornou-se uma espécie de memória coletiva. As viagens de romaria para Bom Jesus de Pirapora e Aparecida do Norte também são eventos que se configuraram nesse sentido. 
A religiosidade é o pano de fundo da vida camponesa. Ela rege os padrões de conduta e chega mesmo a imprimir-se de tal forma que por vezes funciona até mesmo como uma ferramenta (técnica) de que lançam mão nos momentos adversos, por meio de rezas, promessas e benzeduras.

Nos bairros rurais o local do culto religioso é a capela, que em geral está localizada na área central. No Bairro Reforma Agrária, que era um assentamento e tornou-se bairro rural por consequência das relações inter-familiares, não havia uma Igreja. Foi construído um centro comunitário com um local para festas e cultos religiosos. Segundo depoimentos que colhi, o Estado teria feito essa opção devido à presença no assentamento de imigrantes japoneses, cuja religião é budista.

Entretanto, com o passar dos anos, em função da predominância da religião católica, as famílias procuraram transformar o centro comunitário em Igreja. Um pároco de Campinas vai ao Bairro duas vezes por mês celebrar a missa e vários batizados e casamentos foram lá realizados.

A prática religiosa é assim um elemento de socialização no bairro rural, e o local privilegiado para que ela aconteça é a Igreja. Pude ver a fotografia das bodas de ouro de um casal que teve a missa celebrada nesse centro comunitário. Nas fotografias era possível observar que lá estavam presentes pessoas do bairro todo. Assim, o casamento, o batizado, as bodas, não são restritos ao círculo familiar, os vizinhos também tomam parte sessas celebrações.

A palavra vizinho, como foi apontado, é utilizada para qualquer sitiante do bairro, não importa se habite próximo ou não, ou seja, ainda que o sitiante, ao qual chamam de vizinho, tenha seu sítio do outro lado do bairro rural, mesmo assim é vizinho.

Em função da prática religiosa e das famílias julgarem necessário haver um local devidamente apropriado para tal, o centro comunitário (o salão destinado aos cultos religiosos) foi praticamente transformado em Igreja há alguns anos.

Rosane: Tanto que a gente já vinha trabalhando na questão de transformar o que era Centro Comunitário em Capela.

Larissa: Você também estava envolvida nisso?

Rosane: Não, quando o Nelson saiu eu, já estava afastada, mas antes sim, tanto que fizemos uma reunião, não sei precisar a data, pedindo apoio e concordância dos lotistas na hipótese de transformar o Centro Comunitário em Igreja, até aquela casinha 
que tem atrás dela, passar a ser da Igreja, a idéia era, na época, nessa época, construir uma Igreja Católica com a porta voltada pro lado de lá e passar o Centro Comunitário a ser salão, esse era o projeto daquela época. Bom, tudo bem, não aconteceu, mas eu fiquei muito feliz numa coisa, numa coisa eu fiquei muito feliz: a Reforma tem um Sacrário, que isso era um sonho desde já do padre Odair, passou pro Carlos, muitas vezes a Cúria foi conversar com Dom Gilberto a possibilidade, mas por ser Centro Comunitário, a Prefeitura que tomava conta, então toda a questão burocrática no meio, que de documento e lei eu não entendo nada, mas sei que tinha, mas hoje não, hoje a Reforma tem lá o seu Sacrário, e eu acho que isso é uma coisa muito rica dentro do Bairro, eu acredito que numa comunidade onde existe o Sacrário, é que de duas uma: ou o povo tá caminhando, ou povo tá querendo se exibir, e eu acredito que o povo tá caminhando, e eu quero crer nisso. [o Sacrário] É aonde se guarda as óstias consagradas. Em termos de Reforma, de Reforma Agrária, da Comunidade São Sebastião, isso é muito importante, porque eu vou falar de um exemplo pessoal: quando nós éramos ministros, nós tínhamos que distribuir comunhão, nossa, comunguei com a Dona Chica assim muito tempo, pra mãe da Zezé, d. Helena... Então eram duas senhoras impossibilitadas de ir, a d. Chica foi até enquanto pode, numa boa, mas nós passamos a levar Comunhão pra ela direto. Então nós tínhamos missa na época duas vezes por mês, hoje eu não sei como é que tá, primeiro e terceiro sábado, mas a Missa era sete e meia, como cê vai levar a Comunhão pra um enfermo, pra uma senhora, que já não ta... que tá impossibilitada de ir na Igreja, nunca cê sai antes de dez e meia, cê vai visitar a pessoa onze horas? Ou cê vai na casa da pessoa sete horas da manhã. Então o padre na época autorizou... Então pra Reforma, a Instituição do Sacrário veio muito a calhar porque ainda hoje tem muitas pessoas idosas que gostam de receber a Comunhão, mas talvez ela não tem condução, e às vezes ela não tem condição física de estar freqüentando a Comunidade, então se tem o Sacrário, facilita pras pessoas encarregadas da Comunidade a estar levando essa comunhão (...) eu já tinha autorização dele, eu já sabia onde, e sei até hoje, aonde fica guardada a chave no Sacrário, em que lugar está, então eu tinha livre acesso nessa comunidade... por quê? Confiança, e pra Reforma a Instituição do Sacrário foi uma benção mesmo, em termos de Bairro e pras pessoas que não têm condição física. ${ }^{34}$

\footnotetext{
${ }^{34}$ Entrevista com Rosane Furlan, realizada em 25 de fevereiro de 1999.
} 
De fato, a preocupação com a Igreja, o local onde ela deve estar, envolve praticamente todos no bairro rural:

Porque tá tendo missa, a turma tá jogando baralho, falando besteira, num dá, o certo mesmo era trocá de lá, fazer, erguer aqui embaixo, né? Quando eu participei, que eu fui um... é, ajudava tomar conta lá, mas num era presidente, num era nada, né? Aí, podia mudar aqui, fazer aqui pra baixo, né? Mas a turma num quer, diz que queria mudar a porta do lado de cá, mais também num vira nada, né? Fica a mesma coisa, né? Certo mesmo era bem longe do clube, né? Aí podia fazer... é que a turma daqui são muito... muito assim de, num são unido, né? Então podia fazer uma Igreja, fazer um salão de festas, que tinha pessoas que casava, fazia uma festinha, ficava bom, né?

Vê-se que, em consequência da religião predominante própria dos bairros rurais brasileiros, que é a católica, o local foi transformado em Igreja Católica. As festas ligadas à Igreja movimentam todo o bairro rural e são responsáveis pelo convívio estreito entre as famílias que se articulam para prover o necessário para a festa.

Percebe-se que as relações sociais no bairro rural não se "dão no ar”, elas têm os locais privilegiados para acontecer, e estão baseadas nas práticas e ações cotidianas que dão sustentação à vida camponesa.

Não só a Igreja é o ponto de aglutinação do convívio social, como também o bar, a escola e o clube (os dois últimos também localizados no centro comunitário). (

Além destes elementos de coesão (homogeneidade étnica e cultural, tradição comum, parentesco e compadrio) existe outro tipo de interação derivada de necessidades sociais, ligada à presença de serviços, representados principalmente pela igreja, escola e venda... ${ }^{35}$

A escola, local de convívio por excelência das crianças e jovens, é também marcadamente um meio pelo qual as famílias se articulam e convivem. A participação na APM (Associação de Pais e Mestres) é intensa e as famílias movem-se para tomar parte na mesma. Não raros são os mutirões dos pais para eliminar o mato da escola.

A festa junina, promovida pela escola, é freqüentada por todos do Bairro, é um grande momento de encontro, que começa à tarde e se estende ao longo da

\footnotetext{
${ }^{35}$ FERNANDES,1971, p.22.
} 
noite. É um evento em que as pessoas se empenham em participar: não apenas os pais dos alunos, como também os demais membros do Bairro tomam parte em todas as atividades necessárias à festa, desde a arrecadação de prendas até todo o trabalho realizado antes e durante a festa.

Yolanda: Aquelas orquestra, né? Dançava e os fio ficava dormindo.

Larissa: Onde?

Yolanda: Nos colchão lá no fundo, no clube, cê conhece o clube, né? (...) Mais por fora cê conhece, né? Era pequeno, ainda num era assim grande que nem agora, aí ficava dançando... aquelas varsona, que delícia, né!? E as molecada ficava tudo no colchão dormindo. Também (?) ia viajava pra Aparecida do Norte, pra Pirapora, mas antes nós ia no baile primeiro... é, primeiro ia no baile, depois de madrugada, nem vinha em casa, vinha só pegava as coisa, né, pegava a sacola com as coisa que ia levar. Era gostoso, mas agora tá tudo diferente, né?

Larissa: E quando parou de ter esses bailes?

Yolanda: Ah, já faz tempo, faz mais de dez anos que parou. É, depois tinha as música dos jovens, né? Tinha baile dos jovens, agora, faz parece que faiz uns quatro, cinco anos, né Fê, que num tá tendo mais nada, né? ... Agora tem diversão, os rapazes vêm de domingo jogá bola, né? De domingo, sábado de tarde, eles vêm de tarde, jogar bola... tem campo de bocha, né? Mas só que aquelas coisas gostosas, né? Vinha... que nem o meu primo que era radialista, né, eles contratava artista assim, trazia, né, nossa! Ficava até de madrugada fazendo show, é tão gostoso. Agora acabou tudo. Quem sabe algum dia melhora, né?

Larissa: E dessas festas da escola, o pessoal também participava, d. Yolanda?

Yolanda: Ah, participava, nossa! Se um dia tiver uma festa na escola eu vou convidar você pro cê vim, o que é gente que vem! Porque o povo daqui num tem diversão, quando tem, não é só da Reforma, não, vem gente de tudo lado. Vem, nossa, vem tanta gente, vem!... Gostoso! Todo mundo participa, faz, as pessoa ajudava a fazer barraca, fazia aquelas penca de barraca, aquelas fileira. Mas só que participava sim! Agora num tá mais tendo festa, precisava ter, né?

Larissa: E essa quermesse que teve não foi assim como a Senhora está falando?

Yolanda: É, a Laine falou que tinha bastante gente, mas não tanto, tanto, né, tinha mais ou menos, né.

Fernando: É que festa da Igreja o pessoal já num participa tanto, né? Tanto quanto na escola... 
Larissa: É? Por quê?

Yolanda: É porque quando tem festa na escola, é, aqui tem bastante crente, e os crentes participam da festa da escola... Que acho que tem filho na escola, né? Agora, com o crente, tem crente, mas num é tudo, né? Mas tem certa religião crente que não vem na católica. Besteira,né? Que Deus é um só, né? Tem bastante, é a Doutrina da Igreja, né? Essa última festa que teve que meu primo ainda era radialista, agora nem sei, tiraram, acho que tá Indaiatuba, e o programa dele é sertanejo, mas bonito mesmo! Muito lindo, né? Então, a gente, eu liguei lá pra ele: 'Ô Nivaldo, divulga a nossa festa aqui!' Então cada intervalo ele divulgava. Nossa, mas veio tanta gente! Meu Deus, quanta gente que veio! Num tinha lugar de estacionar carro, foi a úrtima festa...

Larissa: Em que ano foi?

Yolanda: Ah, acho que já faiz três anos, acho que três anos já, (...) a úrtima que teve... Festa Junina, depois num lembro se teve outra, não.

Larissa: E festa de São João, ninguém mais faz nos sítios?

Yolanda: Não, antigamente fazia, né? Porque mais foguetero era eu e o meu irmão, né? Como agora a gente é evangélico, a gente deixou de fazer, né? Ih, mai nói fazia cada festança aqui, muié! Fazia, má naquele tampo minha mãe e meu pai era vivo, tudo, né? Agora num tem mais muita graça, mas mesmo assim, quando tem na minha tia, lá, na tia gorda, eu participo.

Larissa: É? É gostoso?

Yolanda: Nossa, vida, uma delícia! Eu sei que o ano retrasado, esse ano eles num fizeram também, houve um problema entre eles lá, né, até aquele dia lá, eu num sei que tinha acontecido que eu vi uma das minhas prima chorando, que na família sempre espirra alguma coisa, né? Então, mais nossa! Larissa, tinha tanta coisa de comer, mas tanta coisa de comer que cê num sabia o que cê comia, que delícia, mas tinha de tudo, de tudo que cê imaginasse que era de comê! Meu Deus, era doce, salgado, de tudo. Saí de lá até mal, de tanto que comi. É farofa, sabe essas farofa de amendoim, aquelas tijelona, que delícia. A gente combinou de fazer de novo esse ano que passou, né, mai daí houve um problema entre elas lá, né? Daí num fizeram. E minha prima Sônia, ela é muita caprichosa, ela enfeitou tudo, mas ela enfeitou tanto que ficou tão lindo! Daí contratou um moço, que até sempre ele vinha tocar na escola, né? Até a gente ficou conhecendo ele na escola memo, né? Que o vereador, pra dá uma força na festa, a 
gente pediu pra ele, ficou conhecendo o Fê, um verador do PT, ficou conhecendo o Fêr, e daí a gente feiz amizade com ele, nós pediu se ajudava um som. Daí ele trouxe o pai e o filho, sabe, eles toca teclado e cantam. Menina!

Da fala anterior há pelo menos dois pontos importantes a serem discutidos: o primeiro é a referência às festas em que todos do bairro participam, que marcadamente são um símbolo da forma de vida no bairro rural, fundamentada na estreita relação entre as pessoas: vizinhos e parentes.

Percebe-se que ao mesmo tempo em que a senhora com quem converso afirma não haver mais festas, em seguida dá um exemplo de uma festa que aconteceu há pouco tempo. Quase sempre nas falas coletadas entre sitiantes há uma nostalgia e afirmação de como o passado era melhor do que o presente, ainda que no momento seguinte seja relembrado um evento atual.

Realmente a expansão das religiões protestantes, evangélicas, trazidas, pelo que pude perceber no trabalho de campo, pelos meeiros, diminui a participação nas festas realizadas pela Igreja ou para a Igreja. Entretanto, as festas realizadas na escola acabam por se caracterizar como uma maneira encontrada no Bairro para que todas as pessoas, independentemente da religião, participem.

O bar é, por excelência, o local de socialização masculina, para onde os homens, principalmente nos finais de semana, se dirigem para beber, conversar, jogar baralho e bocha.

O primeiro bar do bairro surgiu, estrategicamente, ao lado do campo de bocha. O segundo bar está localizado próximo ao clube (centro comunitário) onde também há um campo de bocha e o campo de futebol do clube muito próximo. O terceiro bar que surgiu no bairro também tem ao lado uma quadra de futebol. Nota-se, pela localização espacial desses bares, que todos eles estão estrategicamente localizados na área central do bairro rural e têm junto a eles o local destinado ao jogo.

Pierre Monbeig, em sua obra Pioneiros e Fazendeiros de São Paulo, faz a seguinte observação sobre a localização das “vendas” nos bairros rurais:

Trata-se de sitiantes que, aproveitando o cruzamento, deixaram a agricultura e instalaram-se, não mais perto dos cursos d'água, mas sobre o espigão, abrindo estabelecimentos onde vendem bebidas ou comerciam gêneros alimentícios....

\footnotetext{
${ }^{36}$ MONBEIG, 1984, p.235.

${ }^{37}$ Grifos meus.
} 
É notável, nesse sentido, perceber que os bares do Bairro Reforma Agrária estão também estrategicamente localizados em pontos de necessária passagem para a maioria dos sitiantes. O primeiro deles está exatamente no cruzamento central do Bairro, de onde as estradas se distribuem nas três direções do bairro; a posição da venda é tal que é possível observar todos os que passam na estrada.

Percebe-se que há uma área no bairro onde concentram-se as atividades lúdico-religiosas. Segundo Maria Isaura Pereira de Queiroz, em sua obra $O$ Campesinato brasileiro:

Os bairros rurais se organizam como grupos de vizinhança, cujas relações interpessoais são cimentadas pela grande necessidade de ajuda mútua, solucionada por práticas formais ou informais, tradicionais ou não; pela participação coletiva em atividades lúdico-religiosas que constituem a expressão mais visível da solidariedade grupal; pela forma específica de ajustamento ao meio ecológico, através do trabalho de roça, executado pela família conjugal como unidade econômica e utilizando técnicas rudimentares; pelo exercício do comércio de parte dos gêneros obtidos com a lavoura ou com a criação, como meio de permitir a aquisição de objetos e mercadorias fabricadas na cidade; pela interdependência visível entre o grupo de vizinhança e núcleos urbanos, locais e regionais, para os quais se dirigem os lavradores, seja para vender seus produtos e comprar mercadorias, seja em romarias religiosas, seja para tratar das poucas atividades administrativas e políticas que estão ao seu alcance. Devido a estes caracteres, os sitiantes dos bairros rurais tradicionais se enquadram na classificação de “camponeses”, como os definem os modernos estudos de Sociologia Rural. ${ }^{38,39}$

A inter-relação entre as famílias é tal no bairro rural que todos têm informações a respeito de todos, ou seja, os eventos, sejam eles quais forem, mesmo que no âmbito pessoal, são conhecidos por todos os membros do Bairro. Tanto é assim que aqueles sítios que estão desvinculados do Bairro pelo tipo de uso que deles é feito não são considerados “da Reforma”: “aqui tem já, cê quer ver tem mais ou menos umas dez chácara que já não é mais, não é mais Reforma Agrária entendeu?”.

Muito interessante dizer que esses lotes não são mais Reforma Agrária. Só pertencem ao Bairro Reforma Agrária, ao bairro rural, quando ainda são sítios.

\footnotetext{
${ }^{38}$ QUEIROZ, M. I. P., 1976, p.195.

${ }^{39}$ Grifos meus.
} 
Assim, mesmo estando dentro do espaço físico do bairro, não são considerados como sendo do mesmo.

Há uma intensa teia de relações travada no bairro entre os sítios, além da relação de vizinhança. Paralelamente a esta, há a relação de parentesco (muitas vezes estão mescladas), seja por laços sangüíneos, seja por meio dos casamentos entre as pessoas do próprio bairro (muitas vezes com próprios parentes), que aconteceram desde a formação da “Reforma” e continuam a acontecer até hoje $\mathrm{e}^{40}$.

É realmente impressionante o número de pessoas que se casaram com outras de outros sítios, de tal forma que quase todos têm parentes casados com pessoas de cada família do bairro.

Assim, é comum escutar duas expressões, a segunda sobretudo, típicas do universo camponês vivido por esses sitiantes: “aqui não pode falar mal de ninguém que um é parente do outro” e “aqui um rouba a irmã do outro”.

Os casamentos no Bairro não acontecem apenas entre os próprios sitiantes e destes com pessoas de fora. É significativo o número de casamentos no bairro entre sitiantes e meeiros que para lá foram para trabalhar.

... eles vieram do Paraná... eles são irmão do Jesuíno, tio do, irmão do Jesuíno, são primo do Doni, casado com a filha do Celestino.... um é casado com a filha do Zeolo, um é casado com a filha do Scabello, um é casado com a filha do Cachefo... outro é casado com a... da minha prima... tem outro que é casado com, só tem um que é casado com uma mineira, só um que eu sei que é casado com uma mineira, o resto é tudo casado com... que ele é casado, é uma baixinha do Scabello, casou com Ronaldo... o Negão casou com a irmã do Berinho, lá do Nofre, com a filha do Nofre, a Neusa... outro casou com a filha do Zeolo, outro com a filha do Cachefo, outro casou com a filha do Scabello, só tem dois que casou que num é situante aqui, um é a Maria do seu Ambrósio, e outro casou com uma mineirinha que veio de Minas, o resto é tudo sitiante, e agora o Gordo vai casar com a Selma. ${ }^{41}$

Há um significativo número de casamentos entre sitiantes e meeiros, o que demonstra que a diferença social não é uma barreira, pelo contrário, ainda que a diferença seja percebida, não é de forma alguma um tabu. Esses casamentos acontecem em famílias camponesas, sejam elas ricas ou não.

\footnotetext{
${ }^{40}$ Para detalhes sobre a teia de parentesco ver: Bombardi, 2004.

${ }^{41}$ Entrevista com sr. Luís Antônio, realizada em 12 de agosto de 1999.
} 
Além do trabalho familiar, a relação de trabalho predominante no Bairro é a parceria. Em uma unidade de produção camponesa, em um sítio camponês, todos os seus elementos são determinados pela estrutura familiar. Dessa forma, quando o número de braços da família camponesa é insuficiente para o cultivo da terra de que dispõem, eles lançam mão de algumas formas de suprir sua necessidade de trabalho. De acordo com Tavares dos Santos (1978, p.34):

A análise precedente tentou mostrar que a condição fundamental da produção camponesa é a força de trabalho familiar e que a família é quem provoca a existência de outras relações de produção - o trabalho acessório e o trabalho assalariado - na unidade produtiva camponesa. Antes disso, porém, a família camponesa terá sua capacidade de trabalho complementada pela ajuda mútua entre os vizinhos do bairro rural.

Como vimos, é recorrente no campesinato a prática de ajuda mútua entre os vizinhos, de tal sorte que nenhuma família perca, por exemplo, a sua colheita, ou deixe de fazer um trabalho essencial justamente por falta de quem o faça. Mas essa não é a única forma de resolver o problema da mão-de-obra; para complementar a necessidade de trabalho da família lançam mão de outros trabalhadores, em geral, parceiros (meeiros) com os quais dividem, em troca do uso de suas terras, metade dos custos e metade dos ganhos com a produção. Essa é a relação de trabalho predominante no Bairro Reforma Agrária.

E nós vai tocando o nosso aqui. [Eu pergunto se na parte deles há meeiro.] Na parte nossa tem, é, nós tem lá embaixo o João que toca uma parte lá pra nós, que só nós, eu, o meu irmão, a mulher dele e a minha mulher, nós não vence, né? Não vence, então nós demo, pusemo meieiro lá pra tocar a parte minha, a dele e a parte da minha irmã que pertence pra ela, que é dela... é, o João [o meeiro], então... mora aqui [no sítio], aí então ele toca pra nós lá e nós, eu a mulher e a mulher do meu irmão e o meu irmão, nós toca essa parte aqui de uva e 223 pé de goiaba, já dá pra dançar bem... ${ }^{42}$

Nota-se que a explicação que ele dá para a existência de meeiro na sua propriedade começa pela insuficiência de braços da própria família para cultivá-la: “nós não vence, né?”.

Dessa forma, a presença da força de trabalho familiar é característica básica e fundamental da produção camponesa. É pois derivado dessa característica que a família abre a possibilidade da combinação muitas vezes articulada de outras relações de 
trabalho no seio da unidade camponesa. É assim que o trabalho assalariado, ajuda mútua e parceria aparecem como relações que garantem a complexidade das relações na produção camponesa. Porém essa complexidade de relações estabelecidas é primeiro e fundamentalmente, articulada a partir da família, a partir da hegemonia que o trabalho familiar exerce nessa unidade de produção e consumo.

Já quando a família não consegue completar totalmente a sua necessidade de trabalho, ela pode ser completada pela ajuda mútua entre os camponeses. Essa prática aparece no seio da produção camponesa sob várias formas; a mais comum é o mutirão, mas pode aparecer também como troca de dias de trabalho entre os camponeses. A ajuda mútua é a solução encontrada pelos camponeses para completar o trabalho que a família não conseguiu realizar pois, em geral, seus rendimentos monetários não permitem pagar trabalhadores continuamente. ${ }^{43}$

Através das entrevistas de trabalho de campo, pude perceber que a relação de parceria generalizou-se no Bairro a partir do momento em que o cultivo de frutas também se generalizou, exatamente porque, para esses cultivos, os braços da família são insuficientes para trabalharem todo o sítio. Então lançaram mão desse tipo de relação de trabalho, de forma que toda a terra fosse cultivada.

$\mathrm{Na}$ fala transcrita a seguir, converso com um casal e pergunto a eles por que agora têm meeiros no sítio, enquanto antigamente, quando os pais chegaram e começaram a cultivá-lo, não havia meeiros:

José Marcos: Porque a área de terra ocupa mais gente, porque antigamente milho, você fazia sozinho, plantava bastante área de terra, na goiaba, se for quinhentos pés, precisa ter quatro pessoas, e hoje em dez mil pés [de uva], tem que ter bastante gente, porque eu sozinho não toco.

Regina: ... que nem quando o pai dele vinha aqui era só os filhos, agora os filhos, um foi embora pra cidade. ${ }^{44}$

José Marcos: Mas assim mesmo, se fosse nós oito tocando, a gente não tocava... não dava conta... porque a área, é outra produtividade, né...

Regina: Ela [a fruta] exige muito mais mão-de-obra.

\footnotetext{
42 Entrevista com sr. Luís Antônio Chiquetano, realizada em 19 de fevereiro de 1999.

43 OLIVEIRA, 1991, p.56.

${ }^{44}$ Observar a expressão que ela utiliza, “foi embora pra cidade”, ela não diz apenas foi pra cidade, mas foi embora pra cidade, o que denota um sentido de “apartação” da terra do pai.
} 
José Marcos: Entendeu, ia tocar, se tivesse tudo junto, teria que ter mais casa do que a gente tem agora e mais gente. Agora, antes, que era algodão, o que que era, quiabo, essas coisas, então a gente sozinho se virava.

Regina: Já é uma coisa mais grosseira, ela é delicada, a uva, nossa, tem que passar veneno no tempo certo, amarrar, desbrotar, não pode deixar pra amanhã, ela dá bastante trabalho. ${ }^{45}$

Assim, o trabalho de outrem no sítio camponês só aparece em função da insuficiência dos membros da família para cultivá-lo. O trabalho assalariado, quando ocorre, é esporádico, em geral em épocas de “aperto” na colheita:

... a gente colheu 2.100 caixa de vagem e vendia tudo preço bom, a gente colhia, era eu, meu pai, minha mãe, minha cunhada... e vinha quatro mulher lá da Três Vendas catar vagem pra nós... era de 80 a 120 caixa que nós colhia por dia, aí eu ia vender no Ceasinha, que é na Vila Rica, em Campinas ali. Nossa, os nego tava tudo esperando no trevo... num instantinho, vendia... voltava com os bolso tudo cheio de dinheiro, aqueles tempo ninguém trabalhava com cheque... foi 73 pra 74, então era uma festa, aí deu pra pagar tudo as dívida, bom, num deu pra pagar bem tudo, mas já deu pra pagar uma parte...

Vê-se que, em função da colheita farta, além dos "braços da família", “vinha quatro mulher lá da Três Vendas catar vagem pra nós”; como a colheita foi superior às expectativas da família, foi necessário contratar pessoas para complementar o trabalho.

Entretanto, a presença de trabalho assalariado na unidade camponesa não significa que se configure como uma relação capitalista, segundo Oliveira (1991, p.58):

A presença da força de trabalho assalariada na unidade produtiva camponesa pode também aparecer como um elemento dessa unidade. É evidente, que esse assalariamento no interior da unidade camponesa baseada fundamentalmente no trabalho familiar precisa ser muito bem entendido. Em primeiro lugar, essa contratação, em geral, se deve ao ciclo agrícola em que os membros da família não são suficientes pois as tarefas exigem rapidez e muitos braços... Contrata-se, então, trabalhadores temporários...

Pelo que pude constatar no trabalho de campo, como afirmado anteriormente, no tocante ao tipo de relação de trabalho presente nos sítios do Bairro 
Reforma Agrária, a relação de parceria (meação) é largamente empregada; camponeses sem terra pagam pelo uso da mesma através de renda em produto. Ao final da colheita, o “patrão” divide o ganho pela metade e subtrai desta os gastos que teve com insumos e eventuais “fornecimentos” que tenha feito aos meeiros para que pudessem se reproduzir ao longo do ano agrícola.

Um exemplo bastante claro da baixíssima presença do trabalho assalariado no Bairro Reforma Agrária está na “dificuldade” que uma pesquisadora da área de engenharia agrícola, teve ao tentar identificar qual era o gasto com mão de obra que os proprietários tiveram ao longo de um ano agrícola:

O valor diário atribuído à mão-de-obra foi de acordo com as informações do Instituto de Economia Agrícola e Coordenadoria de Assistência Técnica Integral, sendo de R\$ 8,37, correspondente ao valor médio da Divisão Regional Agrícola (DIRA) de Campinas, em abril de 1995 (IEA, 1996). Esse critério foi adotado devido aos próprios produtores apresentarem dificuldades para informar os valores referentes às operações com mão-de-obra... ${ }^{46}$

Na verdade, a abordagem da unidade camponesa como uma empresa capitalista torna-se completamente ineficaz, pois a lógica que preside o sítio camponês é oposta à da empresa capitalista. O trabalho de outrem no sítio camponês aparece como forma de complementar o trabalho da família e não como meio final de extração da mais-valia, como ocorre nas empresas capitalistas. Assim, segundo Tavares dos Santos (1978, p.43):

Para além da aparência da forma de assalariamento, é preciso considerar a realidade substancial da relação, mediante a análise da condição social das personagens envolvidas. Da parte do camponês que utiliza trabalho assalariado, a finalidade de sua produção é vender um produto para comprar outros que satisfaçam as necessidades de sua família. Em conseqüência, a soma de dinheiro que obtém com a venda de seu produto não se capitaliza, pois o produto excedente não é consumido produtivamente, mas destina-se ao consumo individual da família camponesa. Resulta desse processo que na unidade produtiva camponesa não se constitui o capital que depende da maisvalia gerada pela força de trabalho para se reproduzir em escala ampliada. Em outros termos, não se verifica o desenvolvimento do capital enquanto relação social entre as

\footnotetext{
${ }^{45}$ Entrevista realizada em 10 de fevereiro de 1999.

${ }^{46}$ ZIBORDI, 1998, p.27.
} 
pessoas envolvidas no processo de trabalho camponês. Ao contrário, a forma salário ocorre no interior da produção camponesa em função do ciclo de existência da família. Nesse sentido, a soma de dinheiro gasta no pagamento de salários aparece como redução do rendimento familiar: 'Porque, né, descontando as despesas, pagando empregado e sustentá a família, non dá.’

A relação estabelecida entre os patrões e os meeiros é avessa àquela da racionalidade capitalista. A relação de trabalho presente no sítio não é a relação capitalista, em nenhum sentido, ou seja, não está baseada na extração de mais-valia e o contato patrão-meeiro ou patrão-empregado, via de regra, é feito “de igual para igual”: ... agora nós, a turma fala: 'que aquele ali é meu patrão...', fala: 'Eh, patrão, tem cara de patrão?' [Ele ri.] Patrão, só pra falar, né, não tem nada, acho que nós trabalha mais que os empregado aí, os meieiro,... Uh, hominho ruim pra trabalhar, ainda ele não era dos ruim, sabe, mas tinha o filho dele e o agregado dele que chamava Vicente, cê vê que o bicho era tão nó cego que ele tinha sítio grande lá no Paraná, perdeu tudo, ele era vereador, depois de vereador parece que ficou dois anos, dois mandato conseguiu ficar de vereador e não conseguiu guardar dinheiro, bebia e era atrás de muierada, essas coisa, diz que ele acabou com tudo, mas ruim!... aí a uva começou encontrar, que a uva, se cê deixar ela bagunçar, cê não conserta mais, né? É que ela vai enroscando aquela garra ali, nossa, aí vira uma anarquia. Aí eu via que ele não ia, eu falei: ‘ô, seu Godoy, mas como que...' 'Ah mas minhas criança não vai, num sei o quê', que era pra trabalhar a mulher e a filha dele também, já quando depois, que eu ajustei, já não quis mais trabalhar, aí eu falei: 'Nossa Senhora, tá enrolado hein!' E aquele ano nós tava com financiamento no banco, falei: 'Nossa Senhora, agora se deixar perder tudo aí vai complicar...', aí peguei, fiz um acordo com ele, falei: 'Seu Godoy, vou trabalhar pro sr. uns dia, o sr. pega firme lá porque se o sr. bagunçar com a goiaba, bagunçar com a uva', eu tenho financiamento, e eu fornecia ele ainda, fornecia, comecei com 250, depois do segundo mês em diante ele quis trezentos, aí comecei fornecer e não ia, não ia, não ia. Aí eu peguei e falei: 'Eu vou fazer um acordo com o sr., eu vou trabalhar uns dia aí pro sr. que aí o sr. dá uma adiantada...', aí comecei trabalhar pra ele, eu, meu irmão e minha cunhada, trabalhou pra ele, aí que ele não foi mesmo! Nós trabalhamo um mês e dez dias pra ele, em quatro, nós trabalhamo um mês e dez dias pra deixar a uva tudo limpinha, tudo amarrada, desbrotada, purvarizada, aí eu chamei ele, falei: 'Olha, seu Godoy, o negócio é o seguinte, ó, o sr. não vai, vamo entrar num acordo, eu 
continuo fornecendo o sr. o tanto que eu tô dando pro sr., o sr. só cuida da goiaba, e eu fico com a uva, né?'... ${ }^{47}$

Percebe-se que a relação estabelecida com o meeiro é muito diversa: ele chega a "trabalhar para o meeiro". Evidentemente que, como obterá renda daquilo que foi produzido em seu sítio, tem interesse que essa produção se dê da melhor forma possível. Entretanto, só mesmo em uma relação de trabalho que não tem nenhuma base capitalista o "patrão” trabalha para o próprio “empregado”, que de qualquer forma, tendo sido ajudado, também auferirá maior renda.

O Bairro Reforma Agrária, tendo em vista a proximidade com a periferia de uma metrópole como Campinas, tem enfrentado problemas próprios ao mundo urbano, como por exemplo, assaltos e tráfico de drogas. Entretanto, de forma diferente do que ocorre nas cidades, esses problemas são enfrentados em conjunto, as famílias se reúnem, através do padre (pedem a ele que dirija reuniões), no sentido de se organizarem para evitar a expansão desses problemas no bairro.

Presenciei várias reuniões em 1999 e 2000 nesse sentido. As reuniões foram promovidas na Igreja (Centro Comunitário) e as famílias se articularam para formar uma comissão que se responsabilizasse por resolver os problemas de "violência" vividos no Bairro. Essa comissão, por intermédio do padre, entrou em contato com o chefe de polícia da cidade e com os vereadores. Após contato com os vereadores, estes vieram ao Bairro, em reuniões, e se propuseram a encontrar formas de resolver o problema.

Ao contrário do que muita vezes ocorre nas periferias das grandes cidades, esses problemas são resolvidos em conjunto pela comunidade. Não há um “chefe” responsável pela expansão do narcotráfico ao qual se submetem em troca de proteção. Evidentemente que têm medo de repressões, o que leva alguns membros das famílias a não quererem participar de tal comissão. Entretanto, muitas vezes, analisando a situação do bairro como um todo, mudam de idéia. Na fala a seguir, perguntei a um sitiante por que ele resolveu tomar parte na comissão:

Ah, pra dar uma mão pra turma, né, porque a turma tá com medo, né, ninguém quer entrar... eu acho que não pode ser assim, tem que entrar mesmo, dar um jeito nisso aí... se não fizer nada, que que vai acontecer? Eles vão tomar conta, né? Aí cê não tem mais sossego, já tão roubando carro pra caramba, aí cê não pode mais sair na rua aí, como

\footnotetext{
${ }^{47}$ Entrevista com sr. Luís Antônio Chiquetano, realizada em 19 de fevereiro de 1999.
} 
já não tá podendo quase sair, então tem que tomar providência, tem que ter uma equipe pra ir atrás, consequir as coisas pro Bairro, se não como é que vai fazer? Todo mundo parece que tem medo! Sabe aquele rapaz ontem que saiu de lá, aquele que saiu da comissão, não sei por que, sei lá, um monte de gente tem medo... que nem eu falei pro cara lá, quanto mais tiver, melhor, né? Que ele fala que não precisa tanto assim, né? Porque é só pra representar, porque a gente vai em Valinhos, vai falar com o comandante, vai falar com a polícia, pra ver se consegue montar alguma coisa aqui, que é pro Bairro, pra ter segurança, né?... Há uns tempo atrás, aqui... um mês e pouco, os caras estuprou uma mulher aí... o cara passou de carro, pois ela dentro do carro... chamou a ambulância, levou a mulher pro hospital... ${ }^{48}$

Nota-se que o Bairro é pensado como um todo, as atitudes e decisões são tomadas em conjunto. Assim, ainda que enfrentando problemas típicos do meio urbano, a concepção que rege a vida é outra, as atitudes estão assentadas nos costumes tradicionais, mesmo a poucos quilômetros da metrópole. De acordo com Maria Isaura Pereira de Queiroz (1967, p.109):

Destas observações se depreende, como primeira conseqüência, que o bairro rural tradicional é umas das formas de bairro rural, coexistindo com uma outra forma, a do bairro rural cujos sitiantes, tendo já adotado uma agricultura comercializada, não abandonaram todavia as relações sociais e o modo específico de 'habitat' que definem o bairro rural, o aspecto econômico passa para a segunda plana, deixando na primeira plana o tipo específico de relações sociais e de relações de trabalho. Bairro rural é aquele cujos membros, estando à frente de empreendimentos rurais de que guardam responsabilidade (mesmo quando não conservam a totalidade da colheita), desenvolvem entre si relações de trabalho expressas na ajuda mútua, e conservam relações de vizinhança que se concretizam na participação, em nível social igualitário, das atividades quotidianas e festivas do grupo de localidade. Ao 'sentimento de localidade', de que fala Antonio Candido, ajuntamos a igualdade de posição social entre as famílias. $^{49}$

Percebe-se que aquilo que define a constituição ou não de um bairro rural não é a relação que ele estabelece com o mercado, ou seja, como já foi discutido, o fato dos camponeses do Bairro Reforma Agrária produzirem gêneros quase que

\footnotetext{
${ }^{48}$ Entrevista com sr. Antônio Bregion, realizada em 11 de fevereiro de 1999.

${ }^{49}$ Grifos meus.
} 
exclusivamente para a comercialização, e mais, a despeito de vivenciarem a proximidade com a metrópole, a sociabilidade camponesa é mantida e, por meio dela, o bairro rural se constitui e é a todo o tempo reproduzido: “os vizinho vão indo pra escola, os coleguinha do Bruno vão guardar a bicicleta lá no rancho, depois eles vão pra escola, um é filho do Téia, e o outro é coleguinha dele, que depois, à tarde, eles vêm pegar”. 50

As práticas de ajuda mútua acontecem com freqüência e são também responsáveis pela característica territorial homogênea que o bairro adquire por meio das relações estabelecidas entre as famílias:

É, naquela época que a gente veio morar aqui na Reforma mesmo, até era que nem na Três Vendas, então, vamo supor a gente tava apertado com uma lavoura, a turma que tava forgado num ficava em casa entocado, ou saía pra cidade passear, eles pegava e vinha ajudar e quando a gente tivesse forgado a gente ia ajudar eles, então era uma troca de serviço, ajudava, um num deixava o outro perder mercadoria. Vamo supor, tava apertado pra bater um arroz lá que tava no tempo de bater arroz, então ajuntava um de uma casa, dois da outra, três da outra, então vinha lá, o que que ia levar muitas vez a família inteira pra fazer numa semana ou mais, fazia em dois, três dias, é que nem fosse uma comunidade, né, então um ajudava o outro, a gente ajudava eles, muitas vez que nem nós que plantava tomate, plantava milho, plantava arroz, plantava feijão, então era mais difícil a gente ajudar eles, mas a gente tinha burro, tinha carroça, então a gente emprestava pra eles pra eles fazer o serviço deles, então praticamente ajudava do mesmo jeito, né, que tinha pessoas que num tinha, então a gente ajudava, emprestava burro se a gente num tava usando, então emprestava pra eles tombar terra, que aqueles tempo era tudo no aradinho de burro, então emprestava, então de uma maneira ou de outra ajudava, né, e quando a gente tava assim... tava forgado, a gente ia ajudar, e tinha vez que a gente, quando ia lá, pensava que tinha que fazer o serviço, já tava pronto que os nego já tinha ido e num falava nada, né, sabia que precisava fazer aquele lá, os cara juntava lá e ia, e fazia, e fazia bem feito, né? Num fazia caca não, fazia bem feitinho. Tem vários dele, tinha a turma do Scarpari, tinha que eles eram em três irmão, né? Tinha a turma do Pondian, ajudava, tudo eles, ia embora um, o outro vortava e num conhecia e no fim ficava conhecendo, ia se dando assim, fazendo amizade, continuava igual os outros... [E hoje não tem mais isso?] Ah, hoje não, hoje é

\footnotetext{
${ }^{50}$ Entrevista com d. Yolanda D’Alacqua, realizada em 6 de março de 2000.
} 
cada um pra si e Deus pra todos, se ocê tiver no fosso e tiver ponhando a mão em cima do barranco, se ele puder vir e te dar um chutinho pr'ocê vortar lá pra baixo... [E por quê, o sr. acha?] Porque é a mardita da ganância, né? Um num quer ver o outro bem, né? Um quer procurar de só fazer que aquela pessoa se lasque, né, se dane, né, se exploda. Antigamente não, antigamente, a turma era mais sincero, era mais honesto, tudo, então acho que antigamente era muito melhor do que hoje, hoje cê tem que fazer, e ter fé em Deus pra... porque, se depender de pessoas, num, num vou falar pra você que num tem, né, que tem pessoas boa ainda, mas 90\%, se ele puder te escartar, ele escarta. [Mas alguma coisa vocês fazem, de vez em quando, um para o outro? Outro dia, eu fui no Valter... ele falou que você tinha ido lá passar uma máquina...] De quem? [Do Brombal.] A gente, ele precisa, vamo supor.. que nem, eu tenho picador aqui, tenho rotativa, tenho aquele broca de fazer buraco, então muitas vez eles precisa e eu, se eu tiver meio forgado, eu vou, senão eu empresto, né? Mas assim... falar assim... eu vou sair do meu serviço pra fazer, aí num é fácil não, aí é difícil, mas assim, negócio de maquinário, a gente ainda, pra quem a gente conhece bem, a gente empresta, né? Aí vem pedir emprestado, a gente empresta. Nesses dia mesmo, veio o Osmar emprestar o picador, num é meu, né, tá aí pra mim usar, né, mas eu falei: 'Mas eu num uso aqui, pode levar pra casa e usar... é de um colega meu lá da Três Vendas, então tá emprestado'. Ele falou: 'Ttem aquele picador ainda lá?' Eu falei: 'Tenho...' É pra passar na terra, né? Cortar mato, vai passando com o trator ele vai moendo tudo o mato, vai picando, a gente fala picador, o outro fala grade, então a gente empresta. [Então, máquinav vocês ainda emprestam?) Ainda empresta, só que também cê tem que ver pra quem que cê empresta, que senão cê empresta uma máquina pra quem num tem cuidado e quebra, né, aí... É porque, sei lá, fazendo bem pros outros, acho que num tem problema nenhum, né? ${ }^{51}$

Percebe-se na fala anterior, como em outras citadas, que ao referirem-se ao passado, este aparece representado como uma época em que a solidariedade entre as pessoas era maior, em que havia mais festas, a ajuda mútua era uma prática constante etc. Entretanto, quando pergunto detalhes da prática atual, nota-se que essas práticas ainda estão presentes, entretanto adquiriram outras formas.

Assim, parece que com uma maior especialização dos camponeses no cultivo de frutas, e tendo eles meeiros que complementam a mão-de-obra da família, a

\footnotetext{
${ }^{51}$ Entrevista com sr. Luís Antônio Chiquetano, realizada em 4 de agosto de 1999.
} 
prática de mutirão não mais é necessária. Entretanto, nota-se a constante presença de troca de favores, seja na realização de trabalhos, seja através do empréstimo de instrumentos.

Ele num tá usando [o vizinho não está usando o aspersor] que ele levou lá em Porto Feliz, lá ele num ia usar, tava falando pro Mário, o Zé Preto falou pra ele, ele falou: 'Meus cano tá em Porto Feliz sem fazer nada e vai ficar lá, vai estragar, porque esses cano aqui, se deixar no sol e chuva ele resseca e racha tudo, se ele quisesse usar...', eu já tava meio, daí eu peguei e fui lá em Porto Feliz buscar domingo passado... tá dando certo... Quando tem os outro que empresta assim, é melhor, porque se cê vai comprar, cê vai usar três, quatro vezes, depois cê num vai usar mais, cê vai deixar no rancho guardado, muitas vez o cara sabe que cê tem... que nem nós aqui, eu já marquei tudo quanto expressor emprestou, quanto cano, quanto cano fino... então o dia de emprestar pra ele... ó o tanto que eu emprestei tá aqui, né? Se quebrar algum, eu compro e dou outro... 52

Depreende-se da fala anterior que não apenas acontecem algumas das formas tradicionais de ajuda mútua ${ }^{53}$, mas também outras. Assim, tendo em vista a grande especialização desses camponeses como produtores de frutas, outras práticas surgem como forma de ajuda mútua como, por exemplo, a troca de instrumentos, o empréstimo de caminhões etc.

Desta forma, por meio das influências dos vizinhos, cada família, através do seu trabalho, vai constituindo, formando o seu sítio (unidade camponesa), em um processo contraditório que se consolida no Bairro Rural.

Por isto em trabalho de campo colhi o seguinte depoimento: “ $\mathrm{Na}$ escritura, nos documentos, estava escrito: Núcleo Agrário Capivari. Mas foi a turma que começou a falar... 'eu moro lá no Reforma Agrária', 'eu sou do Reforma Agrária' e ficou”.

Escolhi esta fala para concluir este artigo, pois ela é reveladora daquilo que chamei de identidade territorial: a transformação do nome dado ao assentamento em função do vínculo identitário que as famílias passaram a ter com esta terra e entre si.

\footnotetext{
52 Entrevista com sr. Luís Antônio Chiquetano, realizada em 06 de março de 2000.

${ }^{53}$ Vimos vários exemplos nas falas utilizadas neste artigo, entre outros que coletei no trabalho de campo, como por exemplo, um vizinho fazer o enxerto da uva em troca do outro vizinho "passar a máquina” em seu sítio.
} 
O estabelecimento do vínculo identitário entre as famílias camponeses é o próprio processo de constituição do bairro rural, este, portanto, entendido ao mesmo tempo como identidade e unidade territorial. 


\section{BIBLIOGRAFIA}

BOMBARDI, L. M. O Bairro Reforma Agrária e o Processo de territorialização camponesa. São Paulo: Anna Blume, 2004.

“Movimentos sociais no campo e a ordem moral camponesa”. In: Anais do II Simpósio Nacional de Geografia Agrária/I Simpósio Internacional. São Paulo, 2003, 11p.

CANDIDO, A. Os parceiros do Rio Bonito. $7^{\text {a }}$ edição. São Paulo: Livraria Duas Cidades, 1987.

FERNANDES, L. L. O Bairro Rural dos Pires. São Paulo: IG - Teses e Monografias, 1971.

MONBEIG, P. Pioneiros e Fazendeiros de São Paulo. São Paulo: HUCITEC/Polis, 1984.

MÜLlER, N. L. Tipos de sitiantes em algumas regiões do Estado de São Paulo. São Paulo, 1946. Tese (Doutorado em Geografia Humana) apresentada à Cadeira de Geografia Humana da Faculdade de Filosofia, Letras e Ciências Humanas da Universidade de São Paulo.

OLIVEIRA, A.U. “O Campo Brasileiro no Final dos Anos 80”. In: Boletim Paulista de Geografia, n66, Associação dos Geógrafos Brasileiros, São Paulo, 1988a.

. “Espaço e Tempo, compreensão materialista dialética”. In: Milton Santos

(Org.), Novos Rumos da Geografia Brasileira. São Paulo: HUCITEC, 1988. p.66-110.

A Agricultura Camponesa no Brasil. São Paulo: Editora Contexto, 1991.

QUEIROZ, M.I.P. “Bairros Rurais Paulistas”. In: Separata da Revista do Museu Paulista. Nova série. XVII . São Paulo, 1967.

O Campesinato brasileiro. 2a edição. Petrópolis: Editora Vozes, 1976.

RAFFESTIN, C. Por uma geografia do poder. São Paulo: Editora Ática, 1993.

SADER, M.R., PACHECO, R. Modernidade, Tradição e Ruptura - Algumas Reflexões Sobre Aspectos da Paisagem Rural Brasileira. São Paulo. s.d., 9p. (Mimeogr.).

SHANIN, T. "El campesinado como factor politico”. In: Campesinos y sociedades campesinas. México: Fondo de Cultura Economica, 1979.

La clase incomoda: sociologia política del campesinado en una sociedad en desarrollo (Rusia 1910-1925). Madrid: Alianza Editorial, 1983.

TAVARES dos SANTOS, J. V. Colonos do Vinho. São Paulo: Editora HUCITEC, 1978. . “Camponeses e trajetórias migratórias: Do Sul para a Amazônia Ocidental”. In: Anuário Antropológico, n.91, Rio de Janeiro: Tempo Brasileiro, 1993. p.73.

WOORTMANN, K. Com parente não se neguceia: o campesinato como ordem moral, in Anuário Antropológico/87, pp. 11-73. Brasília/Rio de Janeiro, 1990. 
ZIBORDI, M. S. Sistema de administração rural de um grupo de pequenas unidades produtivas: uma aplicação à fruticultura. Campinas, 1998. Dissertação (Mestrado em Engenharia Agrícola) - Faculdade de Engenharia Agrícola, Unicamp. 